\title{
Increasing the Electrolyte Capacity of Alkaline Zn-Air Fuel Cells via Scavenging Zincate with $\mathrm{Ca}(\mathrm{OH})_{2}$
}

\author{
Aaron L. Zhu ${ }^{\mathrm{a}, *}$, Darek Duch ${ }^{\mathrm{b}}$, Gregory A. Roberts ${ }^{\mathrm{c}}$, Sasha X. X. Li ${ }^{\mathrm{d}}$, Haijiang Wang ${ }^{\mathrm{d}}$, Konrad \\ Duch $^{\mathrm{e}}$, Eunjoo Bae ${ }^{\mathrm{f}}$, Kwang S. Jung ${ }^{\mathrm{f}}$, David Wilkinson ${ }^{\mathrm{a}}$, Sergei A. Kulinich ${ }^{\mathrm{g}, \mathrm{h}, *}$ \\ ${ }^{\text {a }}$ Department of Chemical and Biological Engineering, University of British Columbia, 2360 East Mall, Vancouver, \\ BC, Canada V6T $1 Z 4$ \\ ${ }^{\mathrm{b}}$ Chemistry Division, Power Air Canada Corp., Suite 310, 4475 Wayburne Drive, Burnaby, BC, Canada V5G 4X4 \\ ' Amprius Inc., 1430 O'Brien Drive, Suite C, Menlo Park, CA, 94025, USA \\ ${ }^{\mathrm{d}}$ Institute for Fuel Cell Innovations, National Research Council of Canada, 4250 Wesbrook Mall, Vancouver, BC, \\ Canada V6T 1 W5 \\ ${ }^{\mathrm{e}}$ Faculty of Mathematics, Waterloo University, Waterloo, ON, Canada N2L 3G1 \\ ${ }^{\mathrm{f}}$ H-plus Holding Ltd, 6F J-Tower, 158-3, Seokchon-dong, Songpa-gu, Seoul, 138-844, Korea \\ ${ }^{\mathrm{g}}$ Institute of Innovative Science and Technology, Tokai University, Hiratsuka, Kanagawa, 259-1292, Japan \\ ${ }^{\mathrm{h}}$ School of Engineering and Applied Science, Aston University, Birmingham, B4 7ET, UK \\ Corresponding authors: researchman12001@yahoo.com (A.L. Zhu), skulinich@tokai-u.jp (S.A. Kulinich).
}

\section{Abstract}

The use of calcium hydroxide for scavenging zincate species is demonstrated to be a highly effective approach to increase the electrolyte capacity and improve the performance of the zinc-air fuel cell system. A fundamental approach is established in this study to quantify the formation of calcium zincate as the product of scavenging and the amount of water compensation necessary for optimal performance. The good agreement between predicted and experimental results proves the validity of the proposed theoretical approach. By applying the results of theoretical predictions, both the electrolyte capacity and the cell longevity have been increased by more than $40 \%$. It is also found that using $\mathrm{Ca}(\mathrm{OH})_{2}$ to scavenge zincate species in concentrated $\mathrm{KOH}$ solutions affects mostly the removal of zincate, rather than $\mathrm{ZnO}$, from the electrolyte, while the presence of excess free mobile $\mathrm{H}_{2} \mathrm{O}$ plays a key role in dissolving $\mathrm{ZnO}$ and forming zincate. The results obtained in this study demonstrate that the proposed approach can be widely and effectively applied to all zinc-air cell systems during their discharge cycle.

Key words: zinc-air fuel cell, calcium zincate, zincate, calcium hydroxide, electrolyte discharge capacity. 


\section{Introduction}

After decades of development, lithium-ion batteries are not only being mass-produced but are also gaining acceptance as a viable energy source in electric and hybrid-electric vehicles. Yet, substantial publicly and privately funded R\&D efforts are still underway to address concerns about their cost, safety, and longevity. ${ }^{[1]}$ Although polymer exchange membrane fuel cells (PEMFCs) do show certain advantages over Li-ion batteries, especially when applied in electric vehicles, ${ }^{[2]}$ their state-of-the-technology is still quite far from massmanufacturing and commercialization. And thus there are no near-term alternatives that can outperform the Liion batteries with their combination of high energy and power densities. Hence, alternative chemistries that are inherently safer and less expensive attract increasingly more attention. ${ }^{[3-4]}$ Among them, metal-air batteries and fuel cells represent a new class of promising alternative power sources owing to their remarkably high theoretical energy output. ${ }^{[5-8]}$

Of all metal-air batteries/fuel cells that are currently under development, Zn-air batteries/fuel cells have the most promising potential as they offer an appealing combination of high energy density, addressable technical challenges, low cost and inherent safety ${ }^{[8-11]}$ A renowned example is the low-power primary zinc-air hearing aid battery. ${ }^{[12]}$ With a design combining aspects of conventional batteries and modern fuel cell designs, the currently remodeled Zn-air fuel cell (ZAFC) offers even higher energy densities than its traditional Zn-air battery counterpart. ${ }^{[13-15]}$ Raw material costs for its components (zinc metal, aqueous alkaline electrolytes, inexpensive separator materials, and non-precious metal catalysts for cathode) are low. However, three major barriers keep hindering the ZAFC commercialization: (i) degradation of the air cathode, (ii) low electrolyte capacity, and (iii) difficulties with recharging zinc anodes because of zinc oxide formation.

Unlike Nafion in PEMFCs, mature alkaline polymer membranes have not been fully developed so far. Therefore, potassium hydroxide is still the first choice electrolyte for the ZAFCs. In general, Zn electrochemistry in alkaline electrolytes seems rather simple. The zinc-air chemistry is generally described by the following set of reactions: ${ }^{[14-15]}$

$$
\begin{aligned}
& \text { Anodic reaction: } \mathrm{Zn}+2 \mathrm{OH}^{-} \rightarrow \mathrm{ZnO}+\mathrm{H}_{2} \mathrm{O}+2 \mathrm{e}^{-} \\
& \text {Cathodic reaction: } 1 / 2 \mathrm{O}_{2}+\mathrm{H}_{2} \mathrm{O}+2 \mathrm{e}^{-} \rightarrow 2 \mathrm{OH}^{-} \\
& \text {Overall reaction: } \mathrm{Zn}+1 / 2 \mathrm{O}_{2} \rightarrow \mathrm{ZnO}
\end{aligned}
$$

Accordingly, $\mathrm{ZnO}$ precipitation (given by the overall reaction (3)) may seem favorable. If it is the case, the electrolyte composition should not change during battery operation. However, in reality, the above simple equations hide all the complexity of reactions involving numerous intermediates. ${ }^{[16]}$ Zinc oxidation produces soluble species (equation (4)), i.e. the tetrahydroxyzincate anion (denoted as "zincate" thereafter), which can 
undergo a series of progressive reactions until $\mathrm{ZnO}$ eventually precipitates (equation (5)). Even though the $\mathrm{ZnO}$ precipitation is thermodynamically favored, the zincate anion is metastable, and this is well-known to hinder $\mathrm{ZnO}$ precipitation. In fact, supersaturated zincate solutions with concentrations 2-3 times higher than its equilibrium solubility limit have been reported. ${ }^{[17]}$

$$
\begin{aligned}
& \mathrm{Zn}+4 \mathrm{OH}^{-} \rightarrow \mathrm{Zn}(\mathrm{OH})_{4}{ }^{2-}+2 \mathrm{e}^{-} \\
& \mathrm{Zn}(\mathrm{OH})_{4}{ }^{2-} \rightarrow \mathrm{ZnO}+\mathrm{H}_{2} \mathrm{O}+2 \mathrm{OH}^{-}
\end{aligned}
$$

Also, zincate is always present (at least up to its saturation level) as the first intermediate product of the $\mathrm{ZnO}$ formation. The latter is known to form through a series of intermediates resulted from different steps that lead to changes in the electrolyte balance between zinc ions, $\mathrm{OH}^{-}$and water. ${ }^{[15-16]} \mathrm{ZnO}$ precipitation might be welcomed as it decreases the electrolyte viscosity and therefore should improve the battery's performance, which is technically attractive. However, it also results in a decrease of the electrolyte capacity and therefore can be detrimental for the lifetime of ZAFCs with conventional design, since $\mathrm{ZnO}$ precipitates as an insulating paste and tends to coat the cell components. This can reduce zinc particle-to-particle conductivity and lead to certain mechanical problems. Moreover, $\mathrm{KOH}$ concentration is the lowest at the surface of the zinc particles (where it is being depleted), and low $\mathrm{pH}$ favors $\mathrm{ZnO}$ precipitation. So, it is inevitable that $\mathrm{ZnO}$ precipitation will preferentially occur on the anode and anodic current collector. Hence, improving the electrolyte capacity and minimizing the negative effect of $\mathrm{ZnO}$ deposition become important issues in $\mathrm{ZAFC}$ engineering and development.

It is well known that electrolyte additives, such as potassium silicate, inhibit $\mathrm{ZnO}$ precipitation. When an additive is used, all electrochemically dissolved zincate species are often assumed to remain in the solution. At least, additive species inhibit any heterogeneous precipitation of $\mathrm{ZnO}$ on surfaces, although it is possible that some homogeneous nucleation may occur and then lead to formation of fine particles. This avoids many problems caused by $\mathrm{ZnO}$ precipitation, but it is clear that reaction (4) leads to a certain depletion of hydroxide in the electrolyte due to different reaction rates of reactions (4) and (5) and to accumulation of zincate ions. This decreases the electrolyte conductivity, increases its viscosity, and causes an energy efficiency loss through concentration polarization.

The loss in performance associated with the accumulation of zincate ions and depletion of hydroxide ions has major implications. First, the overall ZAFC performance will decay. Second, the electrolyte has an effective capacity which contributes substantially to the weight and volume requirements of the ZAFC. Clearly, if the dissolved zincate could be stored more efficiently, the weight and volume of required electrolyte could be dramatically reduced. To investigate whether the storage efficiency of zincate could be improved, here we report on a new approach that could possibly provide a simple and efficient solution to the problem. The approach is based on the use of calcium hydroxide as a compound trapping and storing the dissolved 
zincate as a solid. ${ }^{[18-20]}$ The chemistry described in this paper is relevant to any $\mathrm{Zn}$ battery with an alkaline electrolyte. Our preferred approach is to provide the calcium hydroxide in the electrolyte storage tank to minimize interference with the zinc anode, but some battery designs may incorporate calcium hydroxide as a component in the zinc anode. It is also supported by the very recent findings that calcium zincate is beneficial for the zinc electrode, outperforming the mixture of $\mathrm{Ca}(\mathrm{OH})_{2}$ with $\mathrm{ZnO}$ in the $\mathrm{Ni}-\mathrm{Zn}$ battery ${ }^{[21]}$ and acting as a good catalyst for biodiesel production via ethanolysis. ${ }^{[22]}$ According to reaction (6), ${ }^{[19-20]}$ the product forming in the system upon adding calcium hydroxide is calcium zincate:

$$
\mathrm{Ca}(\mathrm{OH})_{2}+2 \mathrm{Zn}(\mathrm{OH})_{4}{ }^{2-}+2 \mathrm{H}_{2} \mathrm{O} \rightarrow \mathrm{Ca}(\mathrm{OH})_{2} \cdot 2 \mathrm{Zn}(\mathrm{OH})_{2} \cdot 2 \mathrm{H}_{2} \mathrm{O}+4 \mathrm{OH}^{-}
$$

Calcium hydroxide is an attractive material for zincate removal for several reasons. First, it is only sparingly soluble in concentrated $\mathrm{KOH}$. The precipitation of any soluble material is not encouraged during cell running since it may block the air cathode pores, resulting in a loss of the cell performance. Second, the product, calcium zincate, is also poorly soluble in concentrated $\mathrm{KOH}$. Therefore, the starting material and the reaction product can be confined in a desired area of the ZAFC. Third, based on some preliminary results obtained in the trial and error tests using mechanically rechargeable zinc fuel cells, calcium hydroxide is expected to have reasonably fast reaction kinetics when it reacts with zincate species in a concentrated alkaline electrolyte. Fourth, from the chemical point of view, one $\mathrm{Ca}$ atom traps two $\mathrm{Zn}$ atoms, which makes $\mathrm{Ca}(\mathrm{OH})_{2}$ an efficient and effective material for removing zincate anions. However, three important issues still need to be addressed:

1. Reports regarding the composition of calcium zincate that forms during chemical reactions between $\mathrm{Ca}(\mathrm{OH})_{2}$ and zincate ions are quite controversial. There are two causes possibly generating the controversy. One is the lack of precise interpretation of crystallographic patterns of the calcium zincate products, while the other is the uncertainty about calcium zincate obtained using the two different prevailing preparative methods, i.e. electrochemical anodic dissolution of zinc in concentrated $\mathrm{KOH}$ and chemical dissolution of $\mathrm{ZnO}$ in waterdiluted $\mathrm{KOH}$. It is imperative to clarify the exact stoichiometric form of the calcium zincate product since this is pertinent to the working efficiency of $\mathrm{Ca}(\mathrm{OH})_{2}$ used in ZAFCs.

2. It is not clear yet how much $\mathrm{Ca}(\mathrm{OH})_{2}$ should be added into the $\mathrm{KOH}$ electrolyte containing zincate, as well as how much extra electrolyte capacity can be acquired by scavenging zincate.

3. The effect of water compensation on maintaining the electrolyte capacity is also generally unknown.

This study presents the results of work on the use of $\mathrm{Ca}(\mathrm{OH})_{2}$ as a scavenger of zincate species with the aim to increase significantly the electrolyte capacity and the longevity of the cell. The aforementioned three key issues are specifically addressed in this report. 


\section{Experimental}

\subsection{Electrochemical tests}

A five-cell ZAFC bipolar stack from Power Air Corporation, which uses inexpensive Zn pellets as the anode material, was used for the electrochemical experiments (an exploded view of an individual cell is shown in Fig. 1). There are many creative designs for $\mathrm{Zn}$-air systems, but this particular study was performed for a $\mathrm{Zn}$-air fuel cell that uses loose $\mathrm{Zn}$ pellets in the anode, an alkaline electrolyte that is pumped through the cell area from a reservoir, and a non-precious metal oxygen-reduction cathode in which oxygen is obtained from the air like a fuel cell. Fresh zinc can be fed into the cell by a gravity-fed hopper as the zinc dissolves, so the ZAFC used in this report could also be classified as a mechanically-rechargeable battery. O-cathode (from eVionyx) and $\mathrm{Zn}$ pellet ( $<1 \mathrm{~mm}$ cut wire shot, Pellets LLC) were used as the cathode and the anode, respectively. $\mathrm{KOH}$ electrolyte (original source: $45 \mathrm{wt}$ \%, in liquid form with $98 \mathrm{wt}$ \% purity, Anachemia) was circulated using a pump connected to the electrolyte tank. A custom-configured Arbin BT2000 batterytesting station (Arbin) was employed for data acquisition and control. Cell polarization and chronopotentiometry curves were used to determine the electrolyte capacity.

\subsection{Analysis of Zn content in $\mathrm{KOH}$ electrolyte}

The total amount of zinc dissolved in the electrolyte was measured with atomic absorption spectrometry (AAS, AAnalyst 200, Perkin Elmer). AAS was selected as the analytical technique for measuring $\mathrm{Zn}$ content owing to its high instrumental sensitivity. Compared to conventional titration, this technique permits to avert the matrix interferences assigned to high $\mathrm{KOH}$ concentrations by applying high dilution factors (250 to 1000 times). Air-acetylene mixture was used as the flame source. A set of five standards ranging from 0.5 ( 0.0 was used as blank) to $16 \mathrm{ppm}$ of $\mathrm{Zn}$ was used to attain a linear absorbanceconcentration curve, with a correlation coefficient greater than or equal to $0.995 .{ }^{[23-25]}$ To control the stability of the system (reading drift), a standard check was applied after each 10 samples (starting from the standard sample with the lowest concentration).

Titration was mainly used to monitor the $\mathrm{OH}^{-}$species in solutions. It was performed using a $\mathrm{R} 24906-$ 52 type Schott Universal Titrator (Cole-Parmer), the detailed measurement procedures being reported elsewhere. ${ }^{[26]}$

\subsection{Calcium zincate formation and crystal structure identification}

The nepheloid layer containing suspended and/or precipitated white powders that could be calcium zincate products was first pumped into a volumetric collecting flask, then filtered by a Millivac Mini filtering system (with pore size $\leq 0.45 \mu \mathrm{m}$, Millipore), and finally dried in a vacuum oven (Cole-Parmer) at $325 \mathrm{~K}$ for

$12 \mathrm{~h}$. The dried powder was then identified by X-ray diffraction (XRD) using a Bruker D8 advanced 


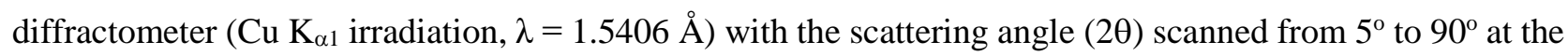
rate of $0.02 \%$. Prior to XRD examinations, the diffractometer was calibrated using an $\mathrm{Al}_{2} \mathrm{O}_{3} \mathrm{NIST}_{-1976}$ standard (Vantec).

\section{$2.4 \mathrm{ZnO}$ detection}

The presence of $\mathrm{ZnO}$ in the precipitates was examined using XRD and energy dispersive X-ray spectroscopy (EDS), the latter unit being attached to the scanning electron microscopy (SEM) instrument (FEI Tecnai G2).

\subsection{Light scattering measurements}

To determine whether colloid species were formed, and to detect and track the occurrence and evolution of $\mathrm{ZnO}$, light scattering spectroscopy (Zetasizer Nano-S, Melvern Instruments) was utilized. Prior to each measurement, the instrument was calibrated by setting the curve of double distilled water or fresh $\mathrm{KOH}$ electrolyte placed in a quartz cuvette as the baseline.

\subsection{Electrolyte preparation and $\mathrm{Ca}(\mathrm{OH})_{2}$ addition}

Additives-free $\mathrm{KOH}$ electrolytes were prepared by diluting a commercial (45 wt. \%) $\mathrm{KOH}$ solution (Anachemia, Fe level below $20 \mathrm{ppm}$ ) with triple distilled water (with resistance $18.2 \mathrm{M} \Omega / \mathrm{cm}$ ) to concentrations from 6 to $10 \mathrm{M}$. $\mathrm{Ca}(\mathrm{OH})_{2}$ (Anachemia, $98 \%$ purity) was mixed with 60 wt. \% PTFE (Dupont, the weight ratio of PTFE to KOH being 1:10), the latter being used as an adhesive agent and powder stabilizer, and then was put into the electrolyte tank at the beginning of the cell run. Alternatively, $\mathrm{Ca}(\mathrm{OH})_{2} \mathrm{was}$ directly added to the electrolyte at the end of cell discharge to form calcium zincate. The solution samples were stirred for $12 \mathrm{~h}$, after which the transparent liquid above the fine powdered precipitation was decanted off, and the precipitate was dried in vacuum oven at $325 \mathrm{~K}$ for $12 \mathrm{~h}$.

In order to realize the highest possible scavenging efficiency of $\mathrm{Zn}$ species dissolved in the cell electrolyte, the work loop used in the present study was designed as follows:

(1) First, it was necessary to clarify the products of the scavenging reactions and then to establish the corresponding reaction equations, so that to obtain accurately the molecular weight ratio of reactive $\mathrm{Ca}(\mathrm{OH})_{2}$ to $\mathrm{Zn}$ dissolved into electrolyte.

(2) Then, it was necessary to measure precisely the content of $\mathrm{Zn}$ dissolved in electrolyte.

(3) Since $\mathrm{Zn}$ dissolved in highly concentrated alkaline electrolyte undergoes a series of complex transitions, all side reactions possible in the entire scavenging process had to be considered, especially those related to and involving water. This was dictated by the necessity to control well scavenging reactions and increase the scavenging efficiency. 
(4) Based on all the above mentioned reaction equations, the calculation approach then could be established to quantify the amount of $\mathrm{Ca}(\mathrm{OH})_{2}$ to be added into the electrolyte for scavenging the dissolved zinc, as well as the amount of water to be added for compensation.

(5) Finally, the scavenging effect was evaluated experimentally, both with and without adding free water, in an industrially used cell presented in Fig.1, after which the work would go back to the above tasks (1) (4) to refine the calculation approach.

\section{Results and Discussion}

\subsection{XRD examination of zinc - calcium product}

$\mathrm{Ca}(\mathrm{OH})_{2}$ was put into the electrolyte tank prior to cell operation. The electrolyte samples taken from the cell outlet at varied cell discharge times were examined using AAS to measure the content of dissolved zinc and evaluate the zincate concentration during cell running. The precipitated products were dried in a vacuum oven and then examined by means of XRD.

In the database, four calcium zincates, $\mathrm{Ca}\left[\mathrm{Zn}(\mathrm{OH})_{3}\right]_{2} \cdot 2 \mathrm{H}_{2} \mathrm{O}, \mathrm{Ca}\left[\mathrm{Zn}(\mathrm{OH})_{3}\right]_{2} \cdot 2 \mathrm{H}_{2} \mathrm{O}, \mathrm{CaZn}_{2}(\mathrm{OH})_{6} \cdot 2 \mathrm{H}_{2} \mathrm{O}$ and $\mathrm{Ca}(\mathrm{OH})_{2} \cdot 2 \mathrm{Zn}(\mathrm{OH})_{2} \cdot 2 \mathrm{H}_{2} \mathrm{O}$ are described, ${ }^{[27-28]}$ and which type of calcium zincate emerges during the ZAFC run depends on the preparation method, water loss and $\mathrm{pH}$. The most compact product of Ca zincate self-polymerization found so far is $\mathrm{Ca}(\mathrm{OH})_{2} \cdot 2 \mathrm{Zn}(\mathrm{OH})_{2} \cdot 2 \mathrm{H}_{2} \mathrm{O} \cdot{ }^{[12-13]}$ The XRD patterns of Ca- $\mathrm{Zn}$ containing products formed respectively after 91 and $200 \mathrm{Ah}$ of cell discharge are presented in Fig. 2. The patterns in Figs. $2 \mathrm{~d}$ and $2 \mathrm{e}$ show that pronounced peaks emerged at 14.15 and $28.55^{\circ}$, which is characteristic of calcium zincate (standard XRD database ICDD file No. 24-222). This strongly suggests that the formed calcium zincate has the structure of $\mathrm{Ca}(\mathrm{OH})_{2} \cdot 2 \mathrm{Zn}(\mathrm{OH})_{2} \cdot 2 \mathrm{H}_{2} \mathrm{O}$. This finding reaffirms previously performed studies on the chemistry of calcium zincate phase. ${ }^{[19-20]}$ Thus, the true scavenging reaction observed in this study appears to be:

$$
2 \mathrm{Zn}(\mathrm{OH})_{4}{ }^{2-}+\mathrm{Ca}(\mathrm{OH})_{2}+2 \mathrm{H}_{2} \mathrm{O} \Leftrightarrow \mathrm{Ca}(\mathrm{OH})_{2} \cdot 2 \mathrm{Zn}(\mathrm{OH})_{2} \cdot 2 \mathrm{H}_{2} \mathrm{O}+4 \mathrm{OH}^{-}
$$

In order to understand the mechanism of reaction between $\mathrm{Ca}(\mathrm{OH})_{2}$ and $\mathrm{ZnO}$ in greater detail, two additional experiments were performed. In experiment $1,1 \mathrm{~g}$ of $\mathrm{ZnO}$ and $1 \mathrm{~g}$ of $\mathrm{Ca}(\mathrm{OH})_{2}$ were added into $200 \mathrm{~mL}$ of double distilled water and stirred for $24 \mathrm{~h}$. Meanwhile, experiment 2 was based on reactions (5) and (6), and therefore $22 \mathrm{~g}$ of $\mathrm{ZnO}$ was mixed with $11 \mathrm{~g}$ of $\mathrm{Ca}(\mathrm{OH})_{2}$ in $200 \mathrm{~mL}$ of $20 \mathrm{wt} \% \mathrm{KOH}$ and stirred for $24 \mathrm{~h}$. The solution was then aged for $6 \mathrm{~h}$ to track the formation of calcium zincate. All the precipitates were dried in vacuum oven at $325 \mathrm{~K}$, and the dry powders and the electrolytes used in the experiments were examined by AAS and XRD. 
In experiment 1 , AAS measurements (with the detection limit of $2 \mu \mathrm{gL}^{-1}$ for $\mathrm{Zn}$ ) indicated no formation of any detectable amount of calcium zincate. Similarly, XRD clearly showed that the electrolyte precipitate was a mixture of $\mathrm{Ca}(\mathrm{OH})_{2}$ and $\mathrm{ZnO}$ (Fig. 3). This suggests that calcium zincate is barely formed via the hydrolysis of $\mathrm{ZnO}$ and $\mathrm{Ca}(\mathrm{OH})_{2}$ in the presence of ample water, since the solubility of both $\mathrm{ZnO}$ and $\mathrm{Ca}(\mathrm{OH})_{2}$ in water is low $\left(1.6 \mathrm{mg} / \mathrm{L}\right.$ and $1.73 \mathrm{~g} / \mathrm{L}$ at $20{ }^{\circ} \mathrm{C}$, respectively), ${ }^{[29]}$ and at least an energy of 6.917 $\mathrm{kJ} / \mathrm{mol}$ is needed to complete the conversion at room temperature. ${ }^{[19-20]}$ It should be mentioned that calcium zincate can be produced by continuous stirring and aging the mixture of $\mathrm{Ca}(\mathrm{OH})_{2}$, water, and $\mathrm{ZnO}$ at a high temperature, ${ }^{[30]}$ or by ball milling. ${ }^{[31-32]}$

In experiment 2, both $\mathrm{Ca}(\mathrm{OH})_{2}$ and $\mathrm{ZnO}$ were found to dissolve sparingly into the $\mathrm{KOH}$ solution upon stirring for $6 \mathrm{~h}$, suggesting a possibility of the calcium zincate formation. The XRD examination (Fig.2c) confirmed a partial formation of calcium zincate. AAS measurements showed that the zinc level in the solution was $86 \mathrm{~g} / \mathrm{L}$, suggesting that almost all the $\mathrm{ZnO}$ was consumed to form calcium zincate, and the coexistence of water and excess $\mathrm{OH}^{-}$is the key factor to provoke the reaction between $\mathrm{ZnO}$ and $\mathrm{Ca}(\mathrm{OH})_{2}$ and the dissolution of the former. $\mathrm{OH}^{-}$may act as a catalyst to promote the hydrolysis of $\mathrm{ZnO}$. The dissolution and dissociation of $\mathrm{ZnO}$ in aqueous $\mathrm{KOH}$ follow the following route: ${ }^{[13,33]}$

$$
\begin{aligned}
\mathrm{ZnO}+\mathrm{H}^{+}+\mathrm{OH}^{-} \Leftrightarrow \mathrm{Zn}^{2+}+\mathrm{O}^{2-} \mathrm{H}^{+}+(\mathrm{OH})^{-} \Leftrightarrow \mathrm{Zn}(\mathrm{OH})_{2} \\
\mathrm{Zn}(\mathrm{OH})_{2}+2 \mathrm{H}^{+} \Leftrightarrow \mathrm{Zn}^{2+}+2 \mathrm{H}_{2} \mathrm{O} \\
\mathrm{Zn}(\mathrm{OH})_{3}{ }^{-}+3 \mathrm{H}^{+} \Leftrightarrow \mathrm{Zn}^{2+}+3 \mathrm{H}_{2} \mathrm{O} \\
\mathrm{Zn}(\mathrm{OH})_{4}{ }^{2-}+4 \mathrm{H}^{+} \Leftrightarrow \mathrm{Zn}^{2+}+4 \mathrm{H}_{2} \mathrm{O}
\end{aligned}
$$

It is expected that in the presence of abundant $\mathrm{OH}^{-}$and free water, $\mathrm{ZnO}$ will dissolve quickly to produce zincate-rich compounds, such as $\mathrm{K}_{2} \mathrm{Zn}(\mathrm{OH})_{4}$, which may couple with $\mathrm{Ca}(\mathrm{OH})_{2}$ to form calcium zincate. We also found that $\mathrm{Ca}(\mathrm{OH})_{2}$ cannot be completely consumed when the $\mathrm{KOH}$ concentration is higher than $37 \%$, as XRD patterns always showed both $\mathrm{ZnO}$ and $\mathrm{Ca}(\mathrm{OH})_{2}$ peaks in the precipitates. This is consistent with the finding of Sharma ${ }^{[19-20]}$ who concluded that water activity in aqueous $\mathrm{KOH}$ with concentrations higher than $34 \mathrm{wt} \%$ is smaller than that in equilibrium with calcium zincate, $\mathrm{Ca}(\mathrm{OH})_{2}$ and $\mathrm{ZnO}$. Thus, $\mathrm{Ca}(\mathrm{OH})_{2}$ cannot suppress the presence of $\mathrm{ZnO}$ in aqueous $\mathrm{KOH}$ anymore.

\subsection{Empirical calculation approach for calcium-zincate formation}

A linear relationship was found between the zinc content in the electrolyte and the cell discharge capacity based on reproducible titrations, AAS, and electrochemical experiments (Fig. 4). In order to affirm the reliability of these results, mathematical simulations were performed using various types of software: MATLAB, MathEmatica and Maple 16. The computational results confirmed strongly the above mentioned 
linearity. The energy equivalent capacity of cell was determined from the amount of reactive zinc in a volume unit $\left(\mathrm{kgL}^{-1}\right)$ and the total quantity of electricity obtained from the zinc involved in electrochemical reactions. The simple linear relationship (Fig.4) suggests that the conversion of dissolved zinc into zincate product in $\mathrm{KOH}$ is straightforward, and no other second-order degree reactions or side reactions occur in parallel. In addition, the slope of the plot can be used to judge the quality of the cell design: the flatter the slope is (the energy conversion efficiency is high), the better the cell design is. Based on the $\mathrm{Ca}(\mathrm{OH})_{2}$ to $\mathrm{Zn}$ ratio in reaction (6), Sharma's reports on the kinetics of calcium zincate formation, ${ }^{[19-20]}$ the report on the decomposition kinetics of supersaturated zincate solutions in reference, ${ }^{[16]}$ the linear relationship between the zinc content in electrolyte and discharge capacity (Fig.4), and the above mentioned XRD results, an empirical calculation approach quantifying the formation of calcium zincate can be established.

The accurate ratios of ionized $\mathrm{Zn}$ to $\mathrm{Ca}(\mathrm{OH})_{2}$, as well as the $\mathrm{Zn}$ being converted to zincate, can be calculated directly according to the molecular weight ratios in reactions (4) and (6). To estimate the water loss resulting from the conversion of $\mathrm{Zn}$ into zincates, assuming that all $\mathrm{Zn}$ dissolved in $\mathrm{KOH}$ electrolyte is converted into zincate form prior to the initiation of $\mathrm{ZnO}$ precipitation, the following calculations were set:

$$
\begin{gathered}
\mathrm{C}_{\mathrm{B}}=\mathrm{C}_{1} \mathrm{D}_{\mathrm{C}}+\mathrm{C}_{2} \\
\mathrm{~W}_{\mathrm{L} 1}=\mathrm{C}_{\mathrm{B}} \cdot \mu_{\text {Zincate/Zn }} \cdot \alpha_{\mathrm{H} 2 \mathrm{O}} \cdot f_{\mathrm{c}} \cdot \mathrm{V}_{\mathrm{E}}
\end{gathered}
$$

Formula (11) is established based on the linear relation between $\mathrm{Zn}$ content in electrolyte and cell discharge capacity, which is found in the AAS measurements. $C_{B}$ is the dissolved Zn concentration in the electrolyte in grams per liter $(\mathrm{g} / \mathrm{L})$, and $\mathrm{C}_{1}$ is the dissolution rate of metallic to ionic $\mathrm{Zn}$ in electrochemical cell. It indeed presents the conversion rate of chemical energy into electrochemical energy and can be represented by the slope of the plot of $\mathrm{Zn}$ content in electrolyte versus electrolyte discharge capacity of the cell. Its unit is gram per Ampere hour (g/Ah), and the value is 1.21 in this work (see Fig. 4). $\mathrm{D}_{\mathrm{C}}$ represents the electrolyte discharge capacity in $\mathrm{Ah} / \mathrm{L}$, and its value can be obtained directly from the electrochemical testing (i.e., total discharge capacity of the cell divided by the electrolyte volume). $\mathrm{C}_{2}$ is the concentration of $\mathrm{Zn}$ dissolved in electrolyte that did not contribute to the generation of energy through the cell circuit (i.e., zinc spontaneously dissolved by corrosion reactions), and it can be represented by intercept of the plot presenting $\mathrm{Zn}$ content in electrolyte versus electrolyte capacity.

Formula (12) is derived based on reaction (6) confirmed by XRD, AAS results, and references. ${ }^{[13,14]}$ It is applied for the calculation of water loss due to metallic $\mathrm{Zn}$ conversion into ionic form presented as zincates. $\mathrm{W}_{\mathrm{L} 1}$ is the water loss in grams due to metallic $\mathrm{Zn}$ conversion into zincates; $\mathrm{C}_{\mathrm{B}}$ is the dissolved $\mathrm{Zn}$ content in

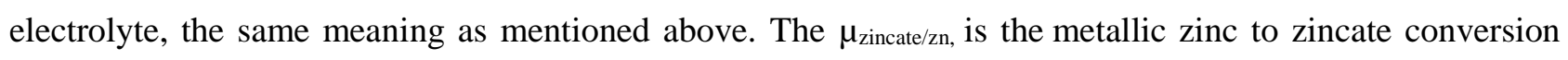
factor (molecular weight ratio of zincate to zinc), 1.52 in this work; $\alpha_{\mathrm{H} 2 \mathrm{O}}$ represents the water weight percentage 
in zincate, 0.233 (see refs. ${ }^{[13,14]}$ ). Regarding $f_{c}$, it is the correction factor to account for water loss during the cell operation time due to evaporation, filtration, etc, (equal to 1.3 in this work) and was obtained from the measurements. $\mathrm{V}_{\mathrm{E}}$ is the volume in liters (L) of used electrolyte.

Formula (13) is utilized to estimate the water loss after $\mathrm{Ca}(\mathrm{OH})_{2}$ treatment:

$$
\mathrm{W}_{\mathrm{L} 2}=\mathrm{W}_{\mathrm{Ca}} \cdot \varepsilon_{\mathrm{CaZincat} / \mathrm{Ca}(\mathrm{OH})_{2}} \cdot \beta_{\mathrm{H} 2 \mathrm{O}} \cdot f_{\mathrm{c}}
$$

Where $\mathrm{W}_{\mathrm{L} 2}$ (in grams) represents the water loss due to calcium zincate formation, $\mathrm{W}_{\mathrm{Ca}}$ is the amount of $\mathrm{Ca}(\mathrm{OH})_{2}$ added into electrolyte. The $\varepsilon_{\mathrm{CaZincate} / \mathrm{Ca}(\mathrm{OH})_{2}}$ is the $\mathrm{Ca}(\mathrm{OH})_{2}$ to calcium zincate conversion factor, it indeed can be calculated from the molecular weight ratio of calcium zincate to $\mathrm{Ca}(\mathrm{OH})_{2}$, the value is 4.17. $\beta_{\mathrm{H} 2 \mathrm{O}}$ is the water weight percentage in calcium zincate, valued as 0.291 based on reaction $(6), f_{\mathrm{c}}$ has the same meaning as aforementioned.

\subsection{Effect of zincate scavenging by calcium hydroxide}

The effect of the zincate scavenging by adding $\mathrm{Ca}(\mathrm{OH})_{2}$ in electrolyte was first estimated theoretically using the derived formula (14):

$$
\mathrm{R}_{\mathrm{T}}=\mathrm{W}_{\mathrm{Ca}} \cdot \Phi / \xi
$$

Where $\mathrm{R}_{\mathrm{T}}$ in $\mathrm{g}$ is the theoretically estimated amount of zinc removed from electrolyte after $\mathrm{Ca}(\mathrm{OH})_{2}$ treatment; $\Phi$ represents the purity of $\mathrm{Ca}(\mathrm{OH})_{2}, 0.95$. $\xi$ is the molecular weight ratio of $\mathrm{Zn}$ to $\mathrm{Ca}(\mathrm{OH})_{2}, 0.57$; note that it was calculated as $2 \mathrm{Zn} / \mathrm{Ca}(\mathrm{OH})_{2}$.

The actual scavenging data was then calculated by formula (15) via using actually measured AAS data.

$$
\mathrm{R}_{\mathrm{A}}=\left(\mathrm{C}_{\mathrm{B}}-\mathrm{C}_{\mathrm{E}}\right) \cdot \mathrm{V}_{\mathrm{E}}
$$

Where $R_{A}$ (in grams) is the actual amount of reduced zinc from the electrolyte, $C_{E}$ (in $g / L$ ) is the concentration of zinc in electrolyte after $\mathrm{Ca}(\mathrm{OH})_{2}$ treatment. The meaning of $\mathrm{V}_{\mathrm{E}}$ has already been mentioned above. On the basis of the derived formulas (11-15), the two most important formulas used to calculate the $\mathrm{Ca}(\mathrm{OH})_{2}$ amount reacted with zincate were developed:

$$
\begin{aligned}
& \mathrm{W}_{\mathrm{Ca}}=\mathrm{R} \cdot \xi \\
& \quad \mathrm{W}_{\mathrm{Ca}}=\left(\mathrm{C}_{\mathrm{B}}-\mathrm{C}_{\mathrm{E}}\right) \cdot \mathrm{V}_{\mathrm{E}} \cdot \xi
\end{aligned}
$$

Where R (in grams) is the amount of dissolved $\mathrm{Zn}$ removed from electrolyte. The other symbols are same as explained above.

Although further experiments pertinent to the quantification of water compensation in the course of calcium zincate formation are needed, the cell tests performed in accordance with the above mentioned empirical calculation theory showed promise as the electrolyte capacity appeared to increase while the cell service life expanded. Table 1 shows that both the theoretically predicted and experimentally measured values for scavenged zinc dissolved in electrolyte are in good agreement, suggesting the validity of the 
applied theoretical approach and that scavenging zincate by means of calcium hydroxide is a selective process that results in calcium zincate. The formation of calcium zincate via hydrolysis of zinc oxide, which is then followed by a direct reaction with calcium hydroxide, is proven to be very slow and therefore can be neglected. Upon adding $\mathrm{Ca}(\mathrm{OH})_{2}$, the zincate anion concentration in $\mathrm{KOH}$ electrolyte can be reduced by approximately $40 \%$ (Figs. 5 and 6). Correspondingly, both the discharge capacity and the electrolyte loading can be increased by more than $40 \%$ (Fig. 7), leading to a significantly improved cell performance (Fig. 8) without the necessity to change the electrolyte. The small reduction (2.1\%) in zinc content upon filtration observed in Fig.6 suggests the formation of some insoluble zincate species, most likely zinc oxide with particle sizes bigger than $0.45 \mu \mathrm{m}$ after a long-time cell non-stop running. The formation of insoluble zinc oxide can be mitigated, or even eliminated through the aging and stirring of a used electrolyte mixed with calcium hydroxide, as was done in experiment 2 described above.

\subsection{Importance of "free water" for $\mathrm{Ca}(\mathrm{OH})_{2}$ treatment and cell performance}

In a $\mathrm{KOH}$ solution, most water molecules typically interact with $\mathrm{OH}^{-}$anions. In this context, "free water" can be defined as water molecules that are mobile enough to link to other chemical groups or species rather than hydroxide anions and whose activity is not significantly reduced compared to that in pure water. It was found that if no small amount of water (less than 1/200 volume fraction) was added into a continuously running cell with $45 \% \mathrm{KOH}$ as electrolyte, the service life of the cell was shorter. In turn, the same cells running with added "free water" demonstrate longer service times of over $250 \mathrm{~h}$, and no noticeable amount of precipitated $\mathrm{ZnO}$ is found by means of filtration and EDS, as well as by AAS measurements for zinc and oxygen contents in the precipitates. This clearly proves that the presence of "free water" in the electrolyte plays an important role in the conversions of zinc into zincate and zincate to $\mathrm{ZnO}$. Such water is believed to be necessary for the release of $\mathrm{OH}^{-}$ions and then to increase their mobility in $\mathrm{KOH}$ in order to fuel and facilitate the anodic reactions (1) and (4). In parallel, in the presence of "free water", an equilibrium chain of reactions is known to be built-up in saturated and supersaturated $\mathrm{KOH}$ solutions, i.e., $\left[\mathrm{Zn}(\mathrm{OH})_{4}\right]^{2-} \leftrightarrow\left[\mathrm{ZnO}(\mathrm{OH})_{2}\right]^{2-} \leftrightarrow \mathrm{ZnO} \cdot{ }^{[16,34]}$ Therefore, the presence of such "free water" will hold back the precipitation of $\mathrm{ZnO}$, increasing the $\left[\mathrm{Zn}(\mathrm{OH})_{4}\right]^{2-}$ concentration in the solution and facilitating the scavenging. It should be borne in mind that $\mathrm{KOH}$ crystallizes when its concentration reaches values above $48 \%$, i.e. in the entire absence of "free water". Using highly concentrated $\mathrm{KOH}$ for gaining power output is expected to result in increased cell resistance. This will decline the cell efficiency and yield additional heat that may potentially damage the polymer materials in the separator and gas diffusion layer, thus causing a running failure of ZAFC. Meanwhile, using $\mathrm{Ca}(\mathrm{OH})_{2}$ to scavenge the zincate also requires water (see reaction (6)). Therefore, water loss and compensation in all the above reactions should be taken into account. The above chapters 3.1-3.3 present a theoretical way to calculate the amount of water needed 
to maintain the equilibria of the reactions. Water that has to be added into the electrolyte to compensate for its loss during conversion processes consists of two components: (1) water consumed for converting $\mathrm{Ca}(\mathrm{OH})_{2}$ into calcium zincate; (2) water used in the conversion reactions of zinc to zincate and zincate to $\mathrm{ZnO}$. Formulas (13) and (14) shown above are proposed to evaluate the total water loss during these two processes. Figure 9 shows how adding water affects the removal efficiency of zincate in an electrolyte with $37 \%$ of $\mathrm{KOH}$ which was discharged at $187 \mathrm{Ah} / \mathrm{L}$. It is clearly seen that without adding water, the deviation from the theoretical line (representing removal of $\mathrm{Zn}$ in an ideal system) appears to begin at about $30 \%$ of $\mathrm{Zn}$ present in the electrolyte. This suggests that increasingly more zincate species dissolved in $\mathrm{KOH}$ cannot be converted into calcium zincate as more $\mathrm{Ca}(\mathrm{OH})_{2}$ is added to the solution. The situation is drastically improved when water is added into the system, as the deviation is only observed when more than $\sim 60 \%$ of $\mathrm{Zn}$ is found in the electrolyte. However, more work is needed to understand better when and how water should be added, since Fig. 9 also shows that not all zincate ions were converted into calcium zincate after adding water into the electrolyte. This fact is consistent with the XRD results in Fig.2d where the presence of minor quantities of $\mathrm{Ca}(\mathrm{OH})_{2}, \mathrm{Zn}(\mathrm{OH})_{2}$, and $\mathrm{ZnO}$ in calcium zincate is seen.

One of the fundamental assumptions used in establishing the above theoretical calculation approach is that the metallic zinc dissolved into highly concentrated $\mathrm{KOH} \mathrm{(>34 \% )} \mathrm{can} \mathrm{be} \mathrm{completely} \mathrm{converted} \mathrm{into}$ zincate ion form (i.e., no significant trace amount of $\mathrm{ZnO}$ is produced in the course of conversion), detained in the saturated and/or supersaturated zincate solution, and then the zincate ions can fully react with calcium hydroxide to form calcium zincate. The appearance of deviation between simulated and experimental results in Fig. 9 suggests that as the cell undergoes discharge, the dissolved zinc may not be completely converted into the zincate form, or the zincate may not be entirely scavenged by calcium hydroxide. This apparent deviation occurs when the electrolyte capacity reaches values over $200 \mathrm{Ah} / \mathrm{L}$ or the cell discharge current density is over $200 \mathrm{~mA} / \mathrm{cm}^{2}$. This suggests that more $\mathrm{ZnO}$ is present in the electrolyte, which was also revealed by XRD measurements. As described in chapter 3.1, the dissolved zinc passes through several stages in $\mathrm{KOH}$ solution until getting converted into zincate ions, and then forms various complexes and oxides. ${ }^{[16 \text {, }}$ ${ }^{34]} \mathrm{ZnO}$ can be scavenged by calcium hydroxide easily when it is firstly converted to zincate in the presence of excess $\mathrm{OH}^{-}$bound with mobile water. Light scattering spectra showed that no evidence of colloid formation was found in saturated and/or supersaturated zincate solutions. For the zincate electrolytes with low discharge capacity, the peaks presenting the particle size of Zn-containing species were centralized at one or two small values, while they gradually became scattered into a larger value range for the electrolytes with discharge capacity over $120 \mathrm{Ah} / \mathrm{L}$, suggesting that zincate species dominate throughout the entire anodic $\mathrm{Zn}$ dissolution, and complex $\mathrm{Zn}$-containing particles can be formed via two stages (homogeneous and heterogeneous ones), which is fully consistent with the findings of Dirkse ${ }^{[35]}$ and Debiemme-Chouvy et al. ${ }^{[16,34]}$ The results 
presented in Fig. 9 show fairly good consistence of theoretical and experimental curves for zinc contents in the electrolyte below $30 \%$, corresponding to the state in which most of zinc dissolved in $\mathrm{KOH}$ electrolyte should exist mainly in the form of $\mathrm{Zn}(\mathrm{OH})_{4}{ }^{2-}$. Note that the presence of zincate ions and $\mathrm{ZnO}$ was traced simultaneously by means of titration, AAS and XRD. This suggests that the best scavenging effect could be obtained as all the dissolved zinc was present in the form of $\mathrm{Zn}(\mathrm{OH})_{4}{ }^{2-}$. The deviation only started to skew severely when the zinc oxide precipitation began. We interpret this finding as a result of a faster formation of $\mathrm{ZnO}$ when it reaches its second stage, i.e. heterogeneous formation. At this point, its formation rate accelerates while its scavenging is much slower than that for the zincate. Dissolving $\mathrm{ZnO}$ by means of water and $\mathrm{OH}^{-}$is known to be very slow. Therefore, the parameters set up in equations (11)-(17) may need to be fine-tuned further in order to be more accurate and reliable, which should be done considering more detailed information on each stage of $\mathrm{ZnO}$ formation. The work can be engaged by initiating zincate-solution kinetic and dynamic studies, as well as setting up an XPS / Auger spectroscopy database for different zincate / ZnO species produced at different cell-discharge states, although it seems rather challenging because the available literature reports are quite scarce to date.

\section{Concluding remarks}

The utilization of calcium hydroxide to scavenge zincate species forming in the $\mathrm{Zn}$-air cell has been proven to be a highly effective approach to improve the cell performance and increase the electrolyte capacity $(40 \%)$. A fundamental calculation approach to quantify the Ca zincate formation and water compensation has been established and tested in this study.

Using $\mathrm{Ca}(\mathrm{OH})_{2}$ to scavenge $\mathrm{Zn}$-containing species in the concentrated $\mathrm{KOH}$ solution was demonstrated to affect mostly the removal of zincate, rather than $\mathrm{ZnO}$, from the electrolyte. However, the presence of excess free mobile $\mathrm{H}_{2} \mathrm{O}$ and $\mathrm{OH}^{-}$helps dissolve $\mathrm{ZnO}$ and form zincate. Replenishing water was demonstrated to increase the percentage of zincate scavenged by means of $\mathrm{Ca}(\mathrm{OH})_{2}$.

The results obtained in this study demonstrate that the proposed approach can be widely applied to all zinc-air systems during their discharge cycle. However, a concern still remains as for how calcium hydroxide will affect the charging cycle, which is important for the development of the next-generation (electrochemically rechargeable) zinc-air batteries and fuel cells. In this context, determining the best method for recovering zinc from calcium zincate becomes an exciting challenge. Literature reports indicate that calcium zincate is unstable in concentrated $\mathrm{KOH}$ solutions above $34 \%$. If a calcium hydroxide "filter" were removed from the battery cell and placed in an electroplating cell with $\mathrm{KOH}$ concentration above 34 $\%$, calcium zincate would start spontaneously releasing some zincate ions. The released zincate ions could be electroplated as zinc on a cathode substrate, thereby stimulating more zincate dissolution from calcium zincate, which is seen as a high-potential in-situ approach for zinc regeneration to be explored and developed 
in the future. Moreover, since calcium zincate was found very recently to provide a beneficial effect on the improved performance of $\mathrm{Ni}-\mathrm{Zn}$ batteries, searching for new preparation routes and applications for calcium zincate is also worth pursuing.

\section{Acknowledgement}

The authors acknowledge sincerely Mrs. Helen Zhu and Dr. Jingwei Hu from AFCC (Mercedes Benz-Ford fuel cell research center, Canada) for their full support during the completion of this research project.

\section{References}

[1] J. M. Tarascon, Phil. Trans. R. Soc. A 2010, 368, 3227-3241.

[2] J. P. Meyers, Getting Back Into Gear: Fuel Cell Development after the Hype, The Electrochemical Society Interface, Winter 2008, pp. 36-39.

[3] B. Peng, J. Chen, Coord. Chem. Rev. 2009, 253, 2805-2813.

[4] F. Cheng, J. Chen, Chem. Soc. Rev. 2012, 41, 2172-2192.

[5] J. Christensen, P. Albertus, R. S. Sanchez-Carrera, T. Lohmann, B. Kozinsky, R. Liedtke, J. Ahmed, A. Kojic, J. Electrochem. Soc. 2012, 159, R1-R30.

[6] Z. Zhang, C. C. Zuo, Z. H. Liu, Y. Yu, Y. X. Zuo, Y. Song, J. Power Sources 2014, 251, 470-475.

[7] C. Z. Shu, E. D. Wang, L. H. Jiang, G. Q. Sun, Int. J. Hydrogen Energy 2013, 38, 5885 - 5893.

[8] J. S. Lee, S. T. Kim, R. G. Cao, N. S. Choi, M. L. Liu, K. T. Lee, J. P. Cho, Adv. Energy Mater. 2011, 1, 34-50.

[9] B. Richter, D. Goldston, G. Crabtree, L. Glicksman, D. Goldstein, D. Greene, D. Kammen, M. Levine, M. Lubell, M. Savitz, D. Sperling, Energy Future: Think Efficiency, American Physical Society, College Park, 2008.

[10] D. J. Mackay, Sustainable Energy - Without the Hot Air, UIT Cambridge, Ltd, Cambridge, U.K., 2009.

[11] K. Kinoshita in Metal/Air Batteries, Electrochemical Oxygen Technology (Eds.: K. Kinoshita), John Wiley \& Sons, Inc., New York, 1992, pp. 19-112.

[12] D. Linden, T. B. Reddy, Handbook of Batteries, 3rd ed., McGraw-Hill, New York, 2002.

[13] X. G. Zhang, Corrosion and Electrochemistry of Zinc, Plenum Publisher, New York, 1996.

[14] S. I. Smedley, X. G. Zhang, J. Power Sources 2007, 165, 897-904.

[15] O. Haas, F. Holzer, K. Müller, S. Müller in Handbook of Fuel Cells, Vol. I (Eds.: W. Vielstich, H. A. Gasteiger, A. Lamm), John Wiley \& Sons, New York, 2003, pp. 382-408.

[16] C. Debiemme-Chouvy, J. Vedel, J. Electrochem. Soc. 1991, 138, 2538-2542.

[17] F. R. McLarnon, E. J. Cairns, J. Electrochem. Soc. 1991, 138, 645-664. 
[18] G. A. Roberts, I. Rehmanji, US 2010/0196768 A1.

[19] R. Sharma, J. Electrochem. Soc. 1986, 133, 2215-2219.

[20] R. Sharma, J. Electrochem. Soc. 1988, 135, 1875-1882.

[21] R. J. Wang, Z. H. Yang, B. Yang, X. M. Fan , T. T. Wang, J. Power Sources 2014, 246, 313-321.

[22] J. M. Rubio-Caballero , J. Santamaria-Gonzalez, J. Merida-Robles, R. Moreno-Tost, M. L. AlonsoCastillo, E. Vereda-Alonso, A. Jimenez-Lopez, P. Maireles-Torres, Fuel 2013, 105, 518-522.

[23] Perkin Elmer Corporation, Perkin Elmer Atomic Absorption Spectrophotometer: System Description and Maintenance, Norwalk, CT, 1982.

[24] Elmer Corporation, Analytical Methods for Atomic Absorption Spectrophotometry, Norwalk, CT, 1982.

[25] J. G. Webster (Eds.), The Measurement, Instrumentation and Sensors Handbook, CRC Press in cooperation with IEEE Press, Boca Raton, 1999, pp. 73-18-73-21.

[26] Z. Kowalski, W. Kubiak, A. Kowalska, Anal. Chim. Acta. 1982, 140, 115-121.

[27] J. O'Neil, Maryadele (Eds.), The Merck Index - An Encyclopedia of Chemicals, Drugs, and Biologicals, Fourteenth Edition, Merck Sharp \& Dohme Corp, Whitehouse Station, 2006.

[28] F. Ziegler, C. A. Johnson, Cem. Concr. Res. 2001, 31, 1327-1332.

[29] W. M. Haynes (Eds.), Handbook of Chemistry and Physics, 93rd ed., CRC Press, Taylor \& Francis Group, Boca Raton, 2012-2013.

[30] S. W. Wang, Z. H. Yang, L. H. Zeng, Mater. Chem. Phys. 2008, 112, 603-606.

[31] X. M. Zhu, H. X. Yang, X. P. Ai, J. X. Yu, Y. L. Cao, J. Appl. Electrochem. 2003, 33, 607-612.

[32] C. C. Yang, W. C. Chien, P. W. Chen, C. Y. Wu, J. Appl. Electrochem. 2009, 39, 39-44.

[33] C. F. Baes, R. E. Mesmer (Eds.), The Hydrolysis of Cations, CRC Handbook, 89th ed., Wiley, New York, 1974.

[34] C. Debiemme-Chouvy, M-Claire Bellissent-Funel, R. Cortes, J. Vedel, J. Electrochem. Soc. 1995, 142, 1359-1364.

[35] T. P. Dirkse, J. Electrochem. Soc. 1981, 128, 1412-1415. 


\section{Figure and table captions}

Figure 1: Exploded view of half-cell assembly used in this study. 1 frame, 2 air cathode, $\mathbf{3}$ copper bar used as current collector, 4 polymer separator, 5 copper mesh, 6 T-shaped copper bus bar bonded to the copper mesh.

Figure 2: XRD patterns of (a) $\mathrm{Ca}(\mathrm{OH})_{2}$, (b) $\mathrm{ZnO}$, (c) precipitate of the electrolyte from experiment 2 (described in chapter 3.1), (d) and (e) precipitates of the electrolyte with $91 \mathrm{Ah}$ and 200Ah discharging, respectively. The background peaks on the $2 \theta$ axis represent the data from the ICDD file No. 24-222.

Figure 3: XRD pattern of precipitate from experiment 1 (described in chapter 3.1)

Figure 4: Linear relationship between zinc concentration in the electrolyte and discharge capacity of the cell. The results are well fitted linearly as: $y=1.2099 x+7.8915\left(\mathrm{R}^{2}=0.9953\right)$.

Figure 5: Reduction in $\mathrm{Zn}$ concentration in electrolyte upon adding $\mathrm{Ca}(\mathrm{OH})_{2}$ to scavenge zincate.

Figure 6: Figure 6: Zinc content change (in \%) in electrolyte upon filtration and treatment with $\mathrm{Ca}(\mathrm{OH})_{2}$. Green columns represent the percentage of zinc content in the tank while violet columns represent the reduced percentage of zinc content after treatment.

Figure 7: Electrolyte loading and capacity gain upon adding $\mathrm{Ca}(\mathrm{OH})_{2}$ to scavenge zincate. Green columns represent the electrolyte loading in $\mathrm{Wh} / \mathrm{L}$ while blue ones represent the discharge capacity in $\mathrm{Ah} / \mathrm{L}$. The numbers marked on the columns present either the maximum loading or the discharge capacity which the electrolyte has reached.

Figure 8: Cell discharge polarization curves (potential versus current, solid circles) and corresponding output power of the electrolyte (dashed lines) before (black) and after (red) treatment with $\mathrm{Ca}(\mathrm{OH})_{2}$.

Figure 9. Effect of adding water on zinc removal from electrolyte by means of $\mathrm{Ca}(\mathrm{OH})_{2}$. Solid line indicates theoretical values of $\mathrm{Zn}$ removal (in \%), while solid circles and empty triangles stand for actually measured values without and with added water, respectively.

Table 1: Theoretically evaluated and experimentally obtained values for zinc reduction in $\mathrm{KOH}$ electrolyte with and without adding $\mathrm{Ca}(\mathrm{OH})_{2}$. 


\section{Table 1}

\begin{tabular}{|c|c|c|c|c|c|c|}
\hline \multicolumn{2}{|c|}{ Reduction in Zn amount based on theoretical approach } & \multicolumn{2}{c|}{ Reduction in Zn amount based on AAS } \\
\hline Term & $\begin{array}{c}\mathrm{Ca}(\mathrm{OH})_{2} / \\
\mathrm{Zn} \text { ratio }\end{array}$ & $\begin{array}{c}\text { Used } \\
\mathrm{Ca}(\mathrm{OH})_{2} \\
\text { weight }\end{array}$ & $\begin{array}{c}\mathrm{Ca}(\mathrm{OH})_{2} \\
\text { Purity }\end{array}$ & $\begin{array}{c}\text { Electrolyte } \\
\text { Volume (L) }\end{array}$ & $\begin{array}{c}\text { Zn before } \\
\text { treatment } \\
(\mathrm{g})\end{array}$ & $\begin{array}{c}\mathrm{Zn} \text { after } \\
\text { treatment } \\
(\mathrm{g})\end{array}$ \\
\hline Input data & 0.57 & 75 & 0.95 & 1.25 & 256.6 & 158.2 \\
\hline $\begin{array}{l}\text { Theoretically } \\
\text { estimated } \mathrm{Zn} \\
\text { reduction }(\mathrm{g})\end{array}$ & \multicolumn{2}{|c|}{$\mathbf{1 2 5}$} & $\begin{array}{c}\text { Actual reduction in } \mathrm{Zn} \\
\text { amount }(\mathrm{g})\end{array}$ & & $\mathbf{1 2 3}$ \\
\hline
\end{tabular}




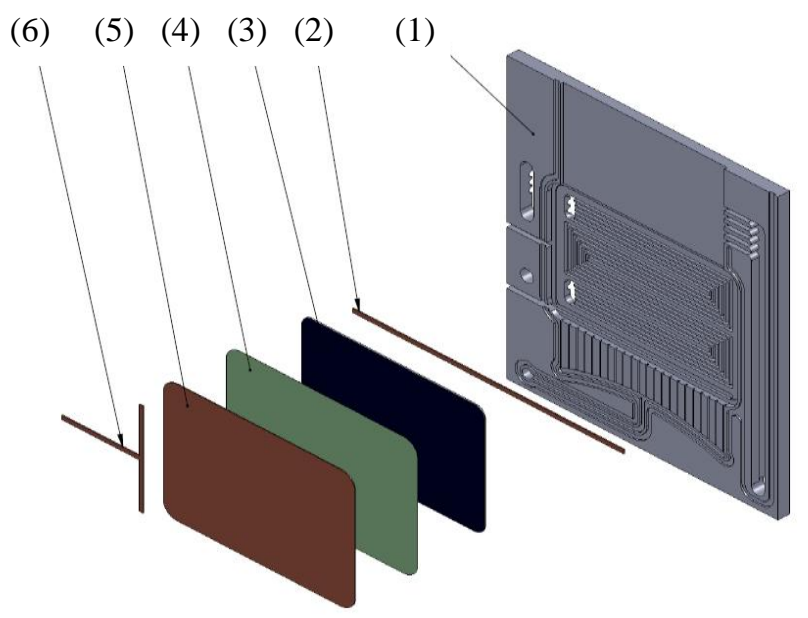

Figure 1: Exploded view of half-cell assembly used in this study. $\mathbf{1}$ frame, $\mathbf{2}$ air cathode, $\mathbf{3}$ copper bar used as current collector, $\mathbf{4}$ polymer separator, $\mathbf{5}$ copper mesh, $\mathbf{6}$ T-shaped copper bus bar bonded to the copper mesh. 


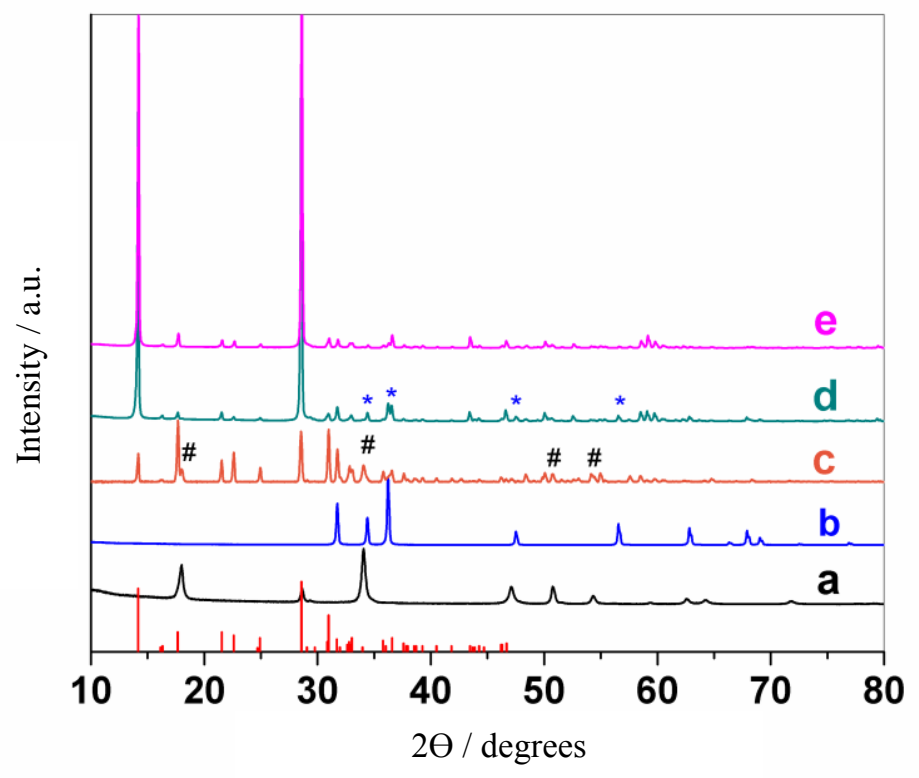

Figure 2: XRD patterns of (a) $\mathrm{Ca}(\mathrm{OH})_{2}$, (b) $\mathrm{ZnO}$, (c) precipitate of the electrolyte from experiment 2 (described in chapter 3.1), (d) and (e) precipitates of the electrolyte with $91 \mathrm{Ah}$ and 200Ah discharging, respectively. The background peaks on the $2 \theta$ axis represent the data from the ICDD file No. 24-222. 


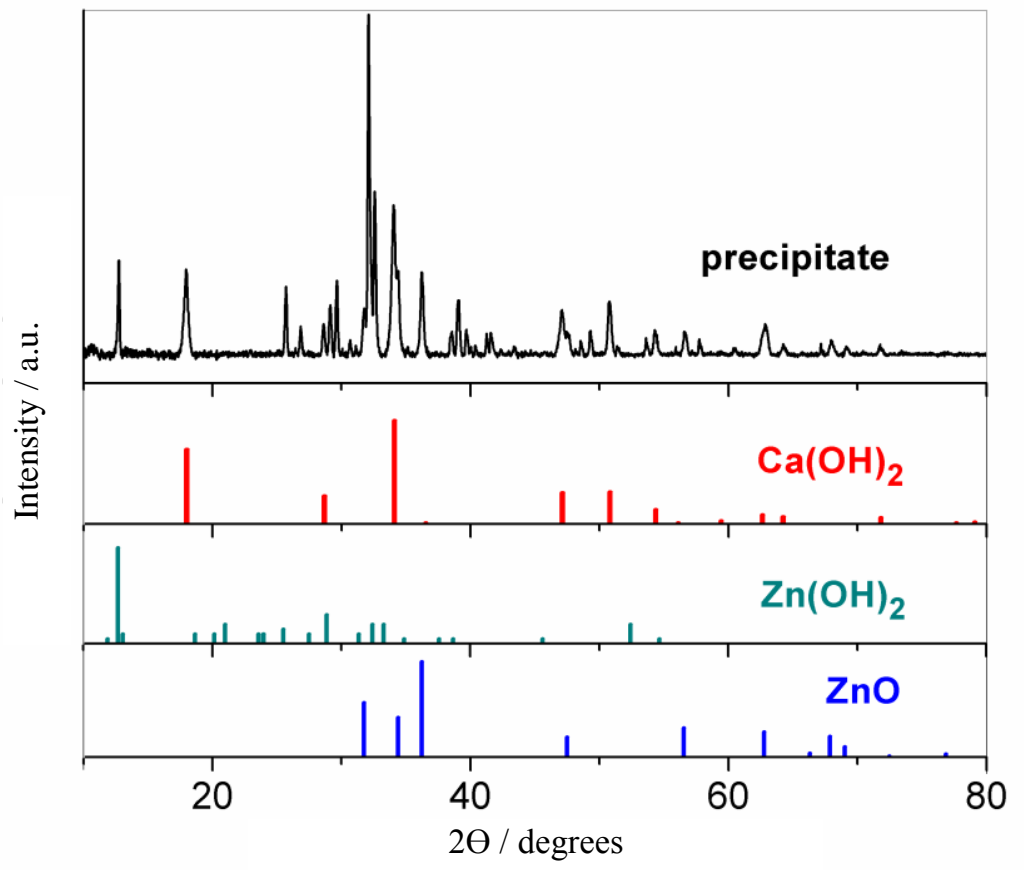

Figure 3: XRD pattern of precipitate from experiment 1 (described in chapter 3.1) 


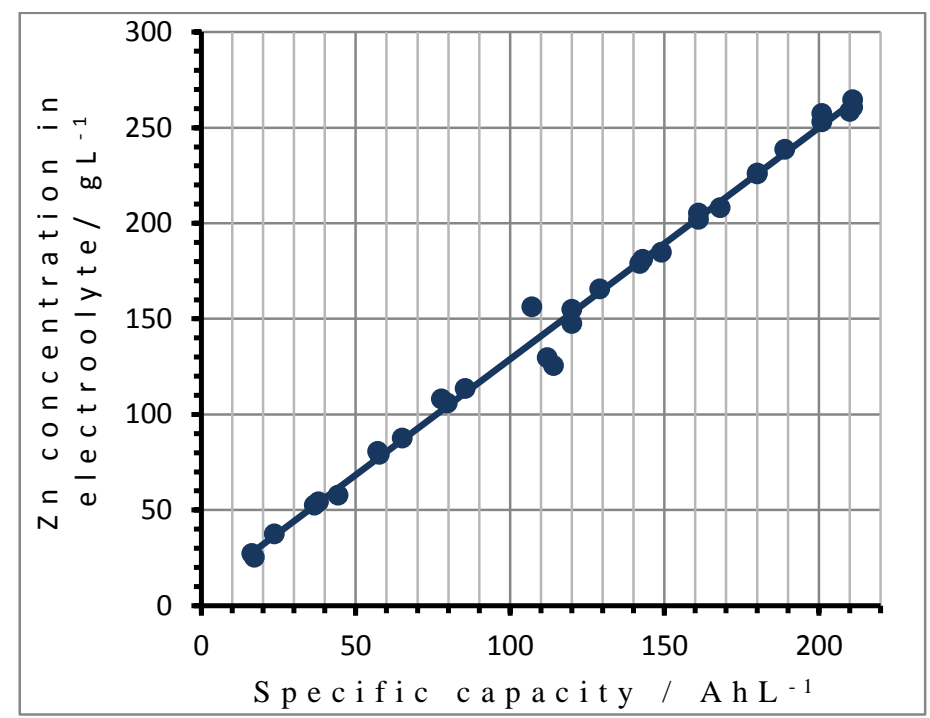

Figure 4: Linear relationship between zinc concentration in the electrolyte and discharge capacity of the cell. The results are well fitted linearly as: $y=1.2099 x+7.8915\left(R^{2}=0.9953\right)$. 


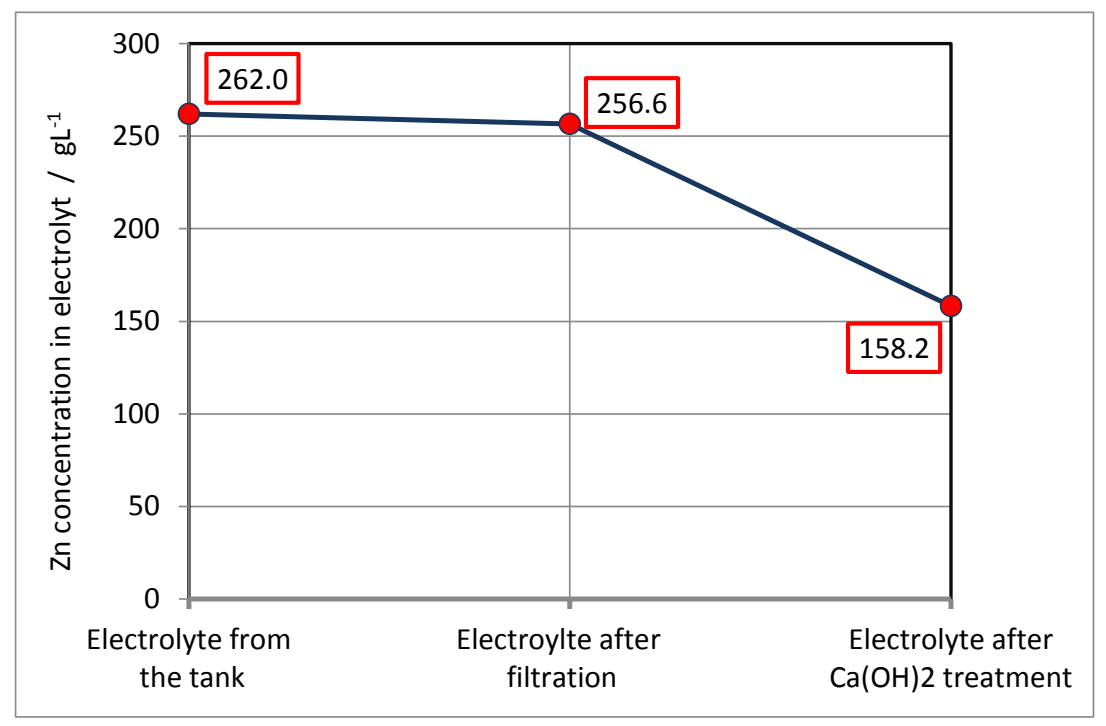

Figure 5: Reduction in $\mathrm{Zn}$ concentration in electrolyte upon adding $\mathrm{Ca}(\mathrm{OH})_{2}$ to scavenge zincate. 


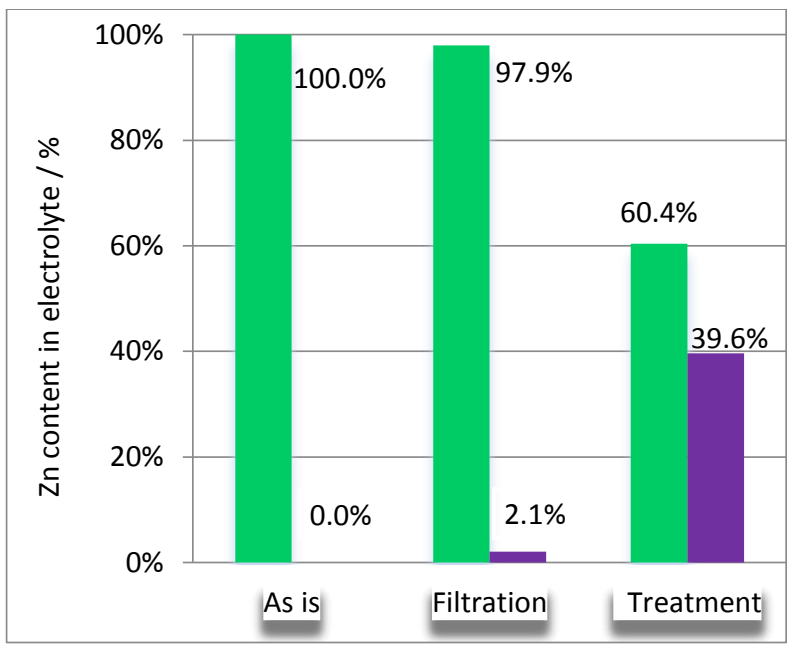

Figure 6: Zinc content change (in \%) in electrolyte upon filtration and treatment with $\mathrm{Ca}(\mathrm{OH})_{2}$. Green columns represent the percentage of zinc content in the tank while violet columns represent the reduced percentage of zinc content after treatment. 


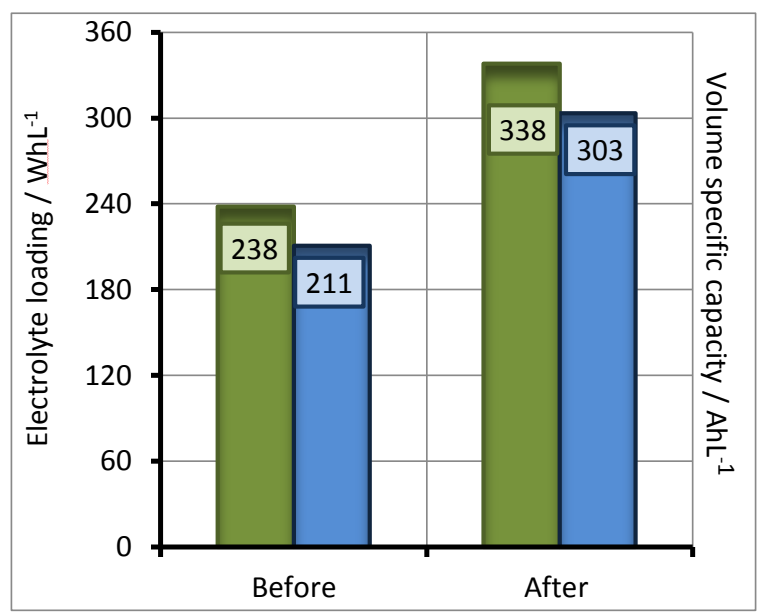

Figure 7: Electrolyte loading and capacity gain upon adding $\mathrm{Ca}(\mathrm{OH})_{2}$ to scavenge zincate. Green columns represent the electrolyte loading in $\mathrm{Wh} / \mathrm{L}$ while blue ones represent the discharge capacity in Ah/L. The numbers marked on the columns present either the maximum loading or the discharge capacity which the electrolyte has reached. 


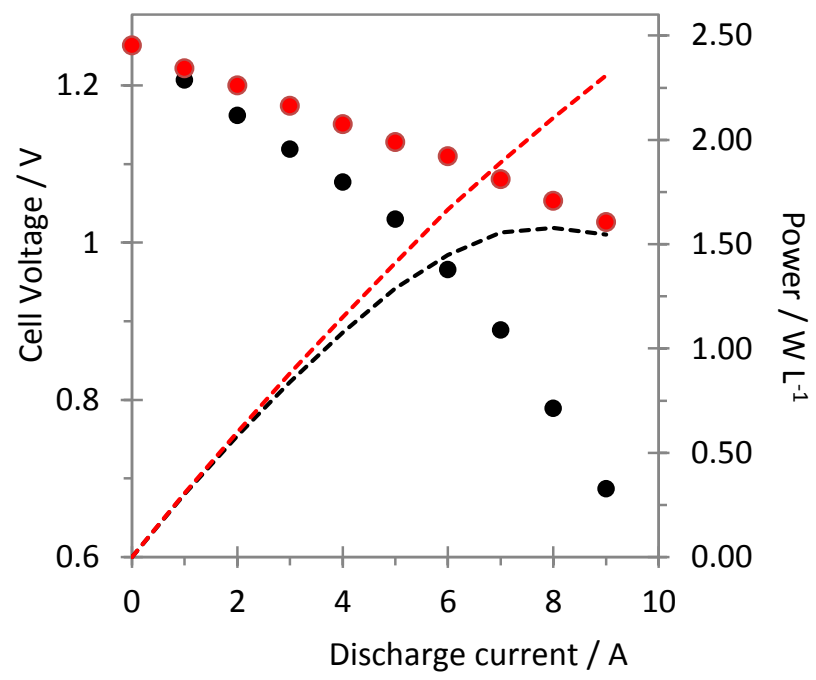

Figure 8. Cell discharge polarization curves (potential versus current, solid circles) and corresponding output power of the electrolyte (dashed lines) before (black) and after (red) treatment with $\mathrm{Ca}(\mathrm{OH})_{2}$. 


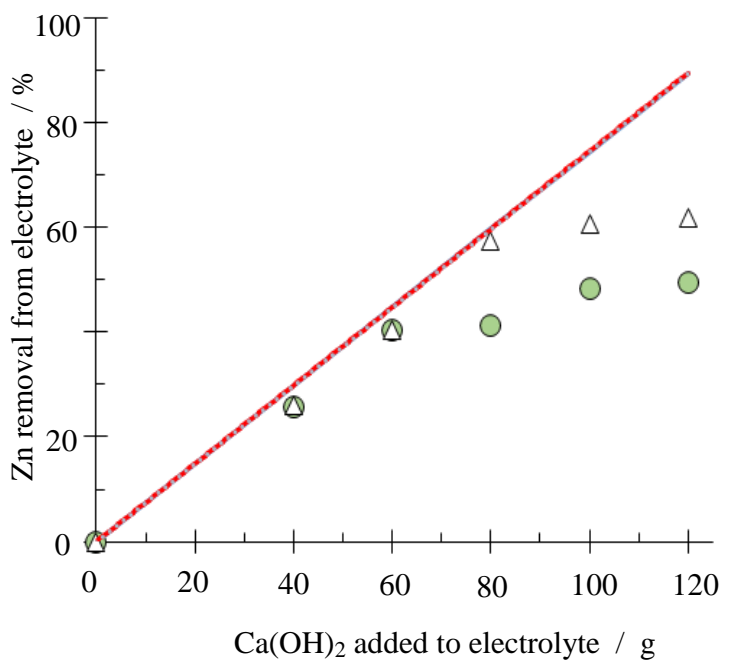

Figure 9. Effect of adding water on zinc removal from electrolyte by means of $\mathrm{Ca}(\mathrm{OH})_{2}$. Solid line indicates theoretical values of $\mathrm{Zn}$ removal (in \%), while solid circles and empty triangles stand for actually measured values without and with added water, respectively. 


\section{Graphical Abstract}

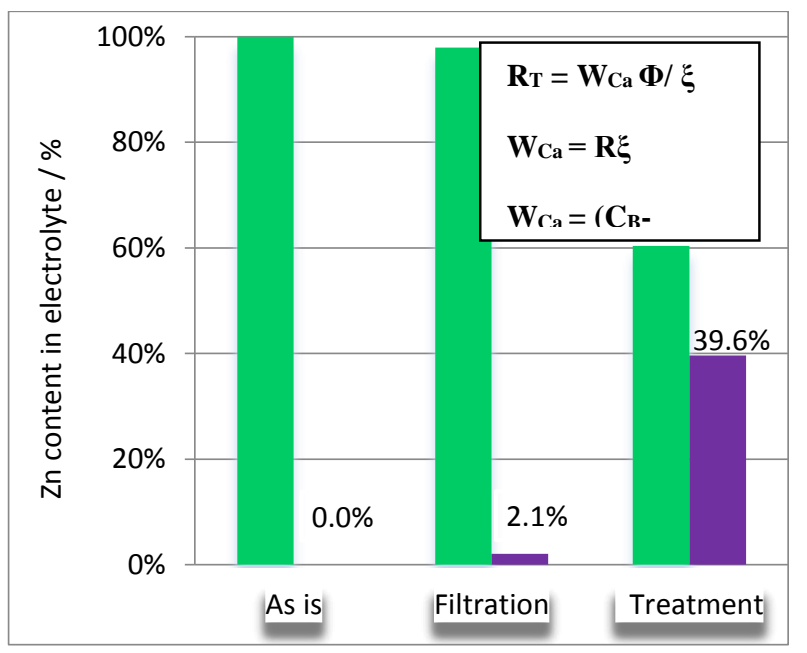

